\title{
Museum as a Communication System
}

\author{
A Preliminary Study on The Condition of University Museums in Indonesia
}

\author{
Ciwuk Musiana Yudhawasthi, Ninies Agustini Damayani, Pawit M. Yusuf, and Asep Suryana \\ University of Padjadjaran \\ Bandung, Indonesia \\ inadhani@gmail.com
}

\begin{abstract}
The idea of establishing university museum in Indonesia had already occurred when the Javanese School of Medicine (Sekolah Dokter Djawa) was established in 1849. Sekolah Dokter Djawa which later was transformed to School tot Opleiding voor Indisch Artsen (STOVIA) was the forerunner of Faculty of Medicine University of Indonesia where the learning and research materials for the first time started to be collected, recorded, maintained and used for medical and medicine sector. Such function is carried out by university museum as the university's supporting department in achieving its vision and mission in education, research and community service. Up to the present, there has never been a study on the existence of university museums in Indonesia. The objectives of this study were to collect the basic information on university museum in Indonesia and to analyze the information within the perspective of communication. The study used explorative qualitative approach and data collection was carried out through literature study, active observation on participants and in-depth interviews with museum managers. The result of the research indicated the importance of communication science use in museology in enhancing communication practices in museums, particularly university museums.
\end{abstract}

Keywords-communication; museum; communication system; museum communication

\section{INTRODUCTION}

Currently the museums have various conditions in the sense of their collections, exhibition models, types of visitors, geographical area and the managers. Despite the varying conditions, in general the museums have the functions of collecting, conserving, researching, communicating and displaying for the purposes of education, study and enjoyment [1]. According to Laurenco, museums that specifically have the extra function in teaching and research are the university museums [2]. The existence of university museum is to support the university's vision and mission in education and research. Therefore generally university museums' collections epistemologically represent their subject disciplines such as anatomy, mineralogy, zoology etc. Epistemologically they also represent the history of the subject discipline, such as physics, chemistry, biology, etc. The strength of university museum becomes the source of its parent institution's pedagogic strength [3]. Essentially the main functions of a university museum are to preserve science materials, provide educational means and to inspire ongoing research [4].
University museums are life laboratories that grow in accordance with the progress of science. University museums also become the basis of learning by directly involving the users with the object [5]. Cameron stated that a museum is a place where people can see, study and use "real things." Those objects are not models or representations of other things, but they are arts or artefacts, made by people or specimens that are scientific phenomena where everything is the culture of a nation [6]. George Scalles of Frances, President of International Council of Museum (ICOM) in Calderon stated that the museum is the only place in the world where "object as interpreter, a language is spoken that everyone can understand". Through the use of a language of a real object, museum communicates with children to adults, the illiterates and those well-educated, the less fortunate and the well-off people [7].

The function of university museum in Indonesia had already existed when Sekolah Dokter Djawa (Javanese School of Medicine) was established in 1849. The Javanese School of Medicine which later was transformed to School tot Opleiding voor Indisch Artsen (STOVIA), was the forerunner of Faculty of Medicine University of Indonesia where the teaching/learning and research materials began to be collected, recorded, maintained and used for the first time for medical and medicine sectors. All the collections can now be accessed in Indonesia Museum of Health and Medicine Faculty of Medicine University of Indonesia or iMuseum FKUI which was recently inaugurated last September 2017. Historically, the presence of an institution carrying out the function of a university museum was carried out for the first time by an educational institution in medicine sector during the Dutch colonial era. But as a formal institution, the oldest university museum in Indonesia is the Biology Museum of Faculty of Biology, University of Gajah Mada in Yogyakarta which was established in 1969 [8]. Currently there are 31 university museums of 23 tertiary educational institutions in Indonesia. Unfortunately the existence of university museum has not been known by the public and even the academician communities in Indonesia. In fact research on this type of museum has never been carried out. Based on the survey carried out by the researcher during May-June 2017 through the social media using snowball method on 50 students of both public and private universities studying in several cities in Indonesia, $95 \%$ of the informants stated their ignorance of any 
university museum's names. It seems that the existence of this type of museum is not widely known and neither has its benefits been felt widely. Apparently communication function and practice in university museum has not been implemented optimally in Indonesia. De Borhegyi, Cameron, Knez and Wrigt, Miles, Mc-Manus and Hooper-Greenhill in Whittle are several professionals that have studied communication process and applied it into museology. Nevertheless their researches focused more on the communication through exhibitions. Whittle explained that there were two categories of communication on museum, namely non-exhibition communication and exhibition related communication [9].

As a preliminary research on university museum, the research is directed to explore the existing communication process; both non-exhibition and exhibition related ones and attempt to analyze a communication system. The queries in the research are formulated as following:

- How is the implementation of communication practice in university museums in Indonesia?

- How is the communication system in university museums in Indonesia?

\section{RESEARCH METHOD}

This research used explorative qualitative approach and data collection was done through literature study, active participants' observation, and in-depth interviews. In doing the literature study, the researcher sought data and information based on literature and reference reviews from books and documents, reports, journals, clippings, magazines, and papers presented in seminars as well as articles from various sources, including the internet and important notes relating to the object of the research. In active participation's observation, the researcher was present and involved in the museums' activities although not fully completed. In-depth interviews were done in person, by telephone and electronic mails to museums' managers. In-depth interview was chosen for the researcher's purpose of obtaining more detailed data on the discussed issues. Observations were done in all university museums and informants for in-depth interviews were selected purposively by taking into consideration the general condition of museum management. Informants amounted to museum managers. Triangulation was done with communication and museum experts.

\section{RESULT AND DISCUSSION}

Referring to museum's division based on types of collection by Ambrose and Paine [10], university museums in Indonesia can be categorized into 5 (five), namely:

- Humanities and Social Sciences. These museums represent the condition of man and society. Artefacts and exhibitions explain human's evolution and creations. Humanities and Social Sciences can be divided into Anthropology, Archaeology, and History sub categories.

- Arts, gallery, and arts museum. Arts museum allows visitors to give their appreciation to arts in the universities. Galleries focus on aesthetics and museums mainly express the history of arts. Additionally, music and architecture museums are included in this category. Nevertheless currently there have not been any university museums on music and architecture in Indonesia.

- Natural History. The natural history museums transform the natural world in objects exhibition. The natural history museum plays the role of supporting scientific research as collection reference. In brief Natural History Museum can be divided into Biology, Geology, Living Museum (Zoo, Botanical Garden and Aquarium) and General Natural History.

- Science and Technology. Science and Technology Museum probably offers similar contents as the Natural History Museum, nevertheless it focuses more on the history of science, technology invention and modern innovation. The collection of this kind of museum is not specifically developed to support researches but also to record the process. Many science and technology museums display interactive exhibitions without any real artefacts. In Indonesia, included in this type of museum are Medicine, Pharmacy, Veterinary, Dentistry and Technology Museums.

- Memorial Hall \& Archives. Archives conserve the history of an institution. Memorial Hall usually contains historical outlines and archives as well as conserving institution related documents.

Up until the present, there are 12 university museums on Humanities and Social Sciences, 2 on Arts, 7 on Natural History, 7 on Science and Technology and 3 university museums in the form of Memorial Hall and Archives in Indonesia. Indonesia also has a university museum presenting Memorial Hall and Archives category, nevertheless its collection is focused more on Medicine (Science \& Technology). The list of university museums in Indonesia is presented in Table 1 below.

TABLE I. TYPES OF MUSEUM UNIVERSITY IN INDONESIA

\begin{tabular}{|c|c|c|c|}
\hline No & University Name & Museum Name & Type of Museum \\
\hline 1 & $\begin{array}{l}\text { Faculty of Medicise Unika } \\
\text { Atmajaya }\end{array}$ & Museum of Anatomy & $\begin{array}{l}\text { Science } \quad \& \\
\text { Technology } \\
\text { (Medicine) }\end{array}$ \\
\hline 2 & $\begin{array}{l}\text { Faculty of Law University } \\
\text { of Indonesia }\end{array}$ & $\begin{array}{lll}\begin{array}{l}\text { Faculty } \\
\text { Museum }\end{array} & \text { Law } \\
\end{array}$ & $\begin{array}{l}\text { Humanities \& Social } \\
\text { Science (History) }\end{array}$ \\
\hline 3 & $\begin{array}{l}\text { Faculty of Medicine } \\
\text { University of Indonesia }\end{array}$ & $\begin{array}{l}\text { Indonesia Museum } \\
\text { of Healt and } \\
\text { Medicine }\end{array}$ & $\begin{array}{l}\text { Science } \quad \& \\
\text { Technology } \\
\text { (Medicine) }\end{array}$ \\
\hline 4 & Trisakti University & $\begin{array}{l}\text { Museum of } 12 \text { May } \\
\text { Tragedy }\end{array}$ & $\begin{array}{l}\text { Humanities \& Social } \\
\text { Science (History) }\end{array}$ \\
\hline 5 & Pelita Harapan University & $\begin{array}{ll}\text { Pelita } & \text { Harapan } \\
\text { Museum } & \\
\end{array}$ & Arts \\
\hline 6 & $\begin{array}{lll}\text { Indonesia } & \text { University } & \text { of } \\
\text { Education } & & \end{array}$ & $\begin{array}{ll}\text { Indonesia National } \\
\text { Educational Museum }\end{array}$ & $\begin{array}{l}\text { Humanities \& Social } \\
\text { Science (History \& } \\
\text { Education) }\end{array}$ \\
\hline 7 & $\begin{array}{lcr}\text { Department } & \text { of } & \text { Plant } \\
\text { Protection } & \text { Faculty } & \text { of } \\
\text { Agricultural } & - & \text { Bogor } \\
\text { Agricultural } & \text { University }\end{array}$ & $\begin{array}{l}\text { Insect Museum Prof. } \\
\text { Soematono } \\
\text { Sosromarsono }\end{array}$ & $\begin{array}{ll}\text { Natural } & \text { History } \\
\text { (Biology) } & \end{array}$ \\
\hline 8 & $\begin{array}{l}\text { University of Sebelas Maret } \\
\text { Surakarta }\end{array}$ & $\begin{array}{lr}\text { University } & \text { Sebelas } \\
\text { Maret } & \text { Museum } \\
\text { Surakarta } & \end{array}$ & $\begin{array}{lll}\text { Memorial Hall \& } \\
\text { Archives }\end{array}$ \\
\hline 9 & $\begin{array}{l}\text { Mardi Wiyata Educational } \\
\text { Foundation Malang }\end{array}$ & $\begin{array}{l}\text { Frater Vianney } \\
\text { Bunda Hati kudus } \\
\text { Zoology Museum }\end{array}$ & $\begin{array}{l}\text { Natural } \\
\text { (Biology) }\end{array}$ \\
\hline 10 & $\begin{array}{l}\text { Faculty of Medicine } \\
\text { Airlangga University }\end{array}$ & $\begin{array}{l}\text { Museum of } \\
\text { Medecine Education }\end{array}$ & $\begin{array}{l}\text { Humanities \& Social } \\
\text { Science (History \& } \\
\text { Education) }\end{array}$ \\
\hline
\end{tabular}


Table I. Cont.

\begin{tabular}{|c|c|c|c|}
\hline 11 & $\begin{array}{l}\text { Faculty of Social and } \\
\text { Political Science Airlangga } \\
\text { University }\end{array}$ & $\begin{array}{l}\text { Museum and Center } \\
\text { for Ethnography } \\
\text { Studies }\end{array}$ & $\begin{array}{l}\text { Humanities \& Social } \\
\text { Science } \\
\text { (Anthropology \& } \\
\text { Education) }\end{array}$ \\
\hline 12 & $\begin{array}{lrr}\text { Department } & \text { of } & \text { Hitorical } \\
\text { Science } & \text { Faculty of } \\
\text { Humanities } & \text { Airlangga } \\
\text { University } & & \\
\end{array}$ & $\begin{array}{l}\text { Museum of History } \\
\text { and Culture }\end{array}$ & $\begin{array}{l}\text { Humanities \& Social } \\
\text { Science (History) }\end{array}$ \\
\hline 13 & $\begin{array}{lrr}\text { Studies } & \text { Center of } \\
\text { Civilization } & \text { Brawijaya } \\
\text { University } & \\
\end{array}$ & $\begin{array}{l}\text { Museum of } \\
\text { Gemstones }\end{array}$ & $\begin{array}{ll}\text { Natural } & \text { History } \\
\text { (Geology) } & \end{array}$ \\
\hline 14 & $\begin{array}{l}\text { Institute if Busins=ess \& } \\
\text { Information - College of } \\
\text { Technology Surabaya }\end{array}$ & $\begin{array}{ll}\text { Museum } & \text { of } \\
\text { Information } & \& \\
\text { Technology } & \\
\end{array}$ & $\begin{array}{l}\text { Science } \\
\text { Technology }\end{array}$ \\
\hline 15 & $\begin{array}{l}\text { Faculty of Medicine } \\
\text { Brawijaya University }\end{array}$ & Anatomy Gallery & $\begin{array}{ll}\text { Science } & \& \\
\text { Technology } & \\
\text { (Medicine) } & \\
\end{array}$ \\
\hline 16 & Yogyakarta state University & $\begin{array}{l}\text { Indonesia Education } \\
\text { Museum }\end{array}$ & $\begin{array}{l}\text { Humanities \& Social } \\
\text { Science (History \& } \\
\text { Education) }\end{array}$ \\
\hline 17 & Gadjah Mada University & UGM Museum & $\begin{array}{l}\text { Memorial Hall \& } \\
\text { Archives }\end{array}$ \\
\hline 18 & $\begin{array}{l}\text { Faculty of Forestry Gadjah } \\
\text { Mada }\end{array}$ & $\begin{array}{l}\text { Museum of Wood } \\
\text { Wanagama }\end{array}$ & $\begin{array}{ll}\begin{array}{l}\text { Natural } \\
\text { (Biology) }\end{array} & \text { History } \\
\end{array}$ \\
\hline 19 & $\begin{array}{l}\text { Faculty of Humanities } \\
\text { Gadjah Mada University }\end{array}$ & $\begin{array}{ll}\text { Museum } & \text { Mandala } \\
\text { Majapahit } & \\
\end{array}$ & $\begin{array}{l}\text { Humanities \& Social } \\
\text { Science (History) }\end{array}$ \\
\hline 20 & $\begin{array}{l}\text { Faculty of Biology Gadjah } \\
\text { Mada University }\end{array}$ & Museum of Biology & $\begin{array}{ll}\text { Natural } & \text { History } \\
\text { (Biology) } & \\
\end{array}$ \\
\hline 21 & $\begin{array}{l}\text { Faculty of Madecine Gadjah } \\
\text { Mada University }\end{array}$ & $\begin{array}{l}\text { Museum of } \\
\text { Paleoantropology }\end{array}$ & $\begin{array}{l}\text { Humanities \& Social } \\
\text { Science } \\
\text { (Anthropology) }\end{array}$ \\
\hline 22 & $\begin{array}{l}\text { Faculty of Geography } \\
\text { Gadjah Mada University }\end{array}$ & $\begin{array}{l}\text { Museum } \\
\text { Geography }\end{array}$ & $\begin{array}{l}\text { Science } \quad \& \\
\text { Technology } \\
\text { (Geography) }\end{array}$ \\
\hline 23 & \begin{tabular}{lr} 
University of & \multicolumn{1}{c}{ National } \\
Development & (Universitas \\
Pembangunan & Nasional) \\
Yogyakarta & \\
\end{tabular} & $\begin{array}{l}\text { Museum of Mineral } \\
\text { Geotechnology }\end{array}$ & $\begin{array}{ll}\text { Natural } & \text { History } \\
\text { (Geology) } & \end{array}$ \\
\hline
\end{tabular}

Although they are said to be university museums, not all of the museums are directly under the management of the university. Several museums are under the management of the faculty even department. Most of the museums are not independent institutions which are directly under the central management (university). As the museum's content which is specifically related to the teaching and research activities, the entire university museums in Indonesia require specialists from related faculty as well as department to maintain the collection and exhibitions. Generally teaching staff at the faculty concerned are the initiators of the museum even after the museum is established they work as museum managers.

Users of university museums in Indonesia can be grouped into internal users from the concerned university namely students, teaching staff, staff of the university or faculty and also the department. Then external users from outside of the university namely the public consisting of high school students, other university's students and teaching staff, teachers, and parents. The museums also interact with the policy makers from various levels namely the government, university, and the faculty. Several museums also interact with foundations as they are privately managed universities. Based on the role and influence on the museums, all of the components are the stakeholders of the museums.

(Illustration 1). The presence of groups of communities, professionals, membership, donors, and board of directors affect the museum's course in the future [11].

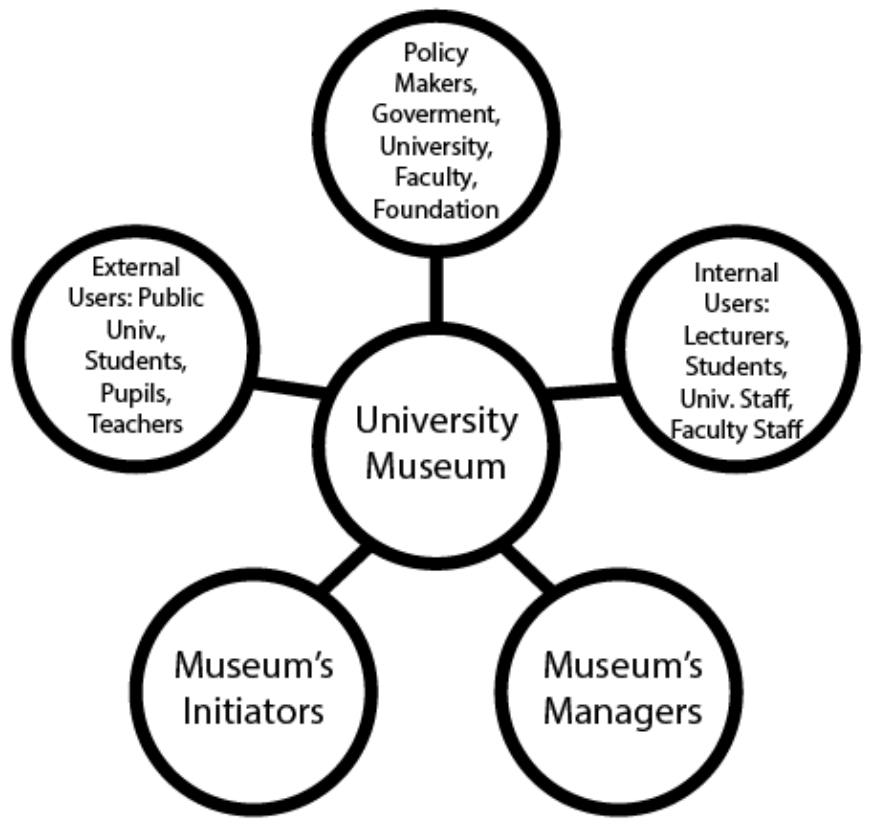

Fig. 1. Analysis Map of University Museum's Stakeholders in Indonesia

According to Hein, in considering how a museum is organized to facilitate learning the museum needs to discuss what should be learned and how it is learned in the museum [12]. Constructivist museum provides opportunities to the visitors to build connection with the known concepts and objects. This stage shows that university museums have messages to be conveyed to build the connection between concepts and objects in facilitating learning; not only to the visitors or users but also to the entire other stakeholders.

Museum is an institution with a complex communication process, in which it can use symbols (primary communication process) as well as using equipment or means as second media after symbols as the first media (secondary communication process). Onong Uchana Effendy explained that communication process essentially is conveying one's thought or feeling to other people [13]. In this case the one conveying the message, message and the recipient of the message in the museum can be described in various dimension by taking into consideration the elements or components of the museum.

University museum is a museum that becomes learning basis by directly involving the user to the object [14]. In constructivist paradigm, learning is knowledge building based on pre-existing knowledge. Learning process is an individual's interpretation of the world. Learning is an active process through interactions or cooperation with other people and learning must be conditioned in real setting. Referring to Hein's opinion (1995) which confirmed that constructivist museum admitted that knowledge is created in visitors' mind thus allowing the museum to accommodate all learning ages. University museum has to develop itself into a museum that can respond to and maximize learning potentials. Objects or things in the museum have unique communication process and can be presented through exhibitions as well as nonexhibition. According to Hooper-Greenhill, museum's main 
product is exhibition, which together with information function, infrastructure, and supporting services they all communicate messages to the public. Additionally access management to the museum also contributes to the entire image of the museum, both physical access and psychological and through museum related information promotion [15].

Generally the objects or things in an exhibition are labelled containing description about the objects or things, but several objects or things that are not labelled can attract users. Actually their mere presence can strengthen the entire message the museum wished to convey. In this case communication process has already occurred. The presence of the creator or the messenger is not necessarily needed in a communication in the museum or even cannot be carried out as the creator or messenger no longer existed for decades or centuries. Low social presence level in such non-verbal communication will create various interpretations and meanings of the objects or things. This will give various nuance and value not only to the managers of the museum but also to the stakeholders. This condition makes the museum more "alive" due to the variety of values and experiences that can be sensed. It is the values and experiences felt by the stakeholders that need to be extracted and constructed continuously by the museum to meet the needs of various users in addition to the museum formulating and constructing the values based on the vision and mission of its parent institution.

Littlejohn stated that communication system is a set of integrated variables interaction in which they together create a bigger pattern [16]. University museum is a communication system with objects, attributes, internal relation and nonvacuum environment. Objects in museum system can be analyzed as following,

- creator/messenger: museum person, i.e. creator of the object or thing (museum collection), director of the museum, curator, Museum Association, guide

- message: museum collection (objects or things). And also news, opinions, advertisements which are probably made by the museum as an institution,

- Recipient of the message: interested people or the stakeholders,

- media: exhibitions, mass media, social media

- effects are highly dependent on the message and the media used. The easiest effects to be viewed are the increasing number of visits, the increasing museum's facilities and services, budget increase etc.

- feedback

Their characteristics or qualities as objects are the attributes of the system. The interactions between objects create relationships among members of the system. The museum's system also exists in social, political and cultural environment. Members of the systems are interdependent which means the museum is influenced by the people and also the government. The museum system has its own regulations for the system and its members. The regulations among others are Law No. 10 of 2010 on Cultural Heritage and Government Regulation No. 66 of 2015 on Museum. Members of the system should behave in accordance with the applicable regulation in the system. Control mechanisms are also implemented to take the next step on members of the system behaving deviantly. The control mechanisms in the system are executed by the Association of Indonesian Museums. The museum system is in a social system, political system, cultural system, economy system and many more. All of those systems are influencing one another. The balance of a system correlates with the ability to maintain itself; discipline, obedient, capable of adjusting/revising regulations that are not in line with the development of the system as well as the environment. The system should also be adaptable with its environment, adjusting itself to the environmental changes.

Current museum paradigm shift which previously was oriented on the object to being oriented to human brings the impact on the museum being the place to build social interactions or the "Third Place" [17]. Professor Ray Oldenburg explained as the "Third Place" a museum is expected to be a destination after home and work place by healthy society [18]. Not only the museum provides the information needed but also it becomes a pleasing place for all, which means the museum is capable of meeting the needs of various visitors, including the needs of people with special needs and adapting itself to technology progress. The museum provides opportunities to the visitors to connect with known concepts and objects [19].

From field observations can be seen that most university museums are not aware of their position in a communication system hence they cannot pay attention to the elements and physical and abstract variables that are the strength of university museum in communicating. For instance most of university museums rely on the idea that museum's collection objects or things are communication media instead of message. Museum's objects or things are not just nonverbal language phenomena that are observable. Actually in certain dimension, objects or things can be placed as messenger or message creator. In the context of intrapersonal communication, the communication carried out by user to an object or thing can directly produce certain behavior which currently is being studied much, for example imagining (Engen, 2002) and dreaming process (Iljam \& Miller, 2000). West and Turner confirmed that the behavior that focused on the role of oneself in the communication process is the heart of one's communication activities [20]. To illustrate, below is a photo taken during observation in a university museum (Illustration 2). It is shown in the photo that the message recipient seemed to focus on cognition, symbol and intention in her mind. The object in the photo is preparation for baby. The preparation is the message conveyed by the Creator (as the message creator) and is communicated through exhibition in museum. 


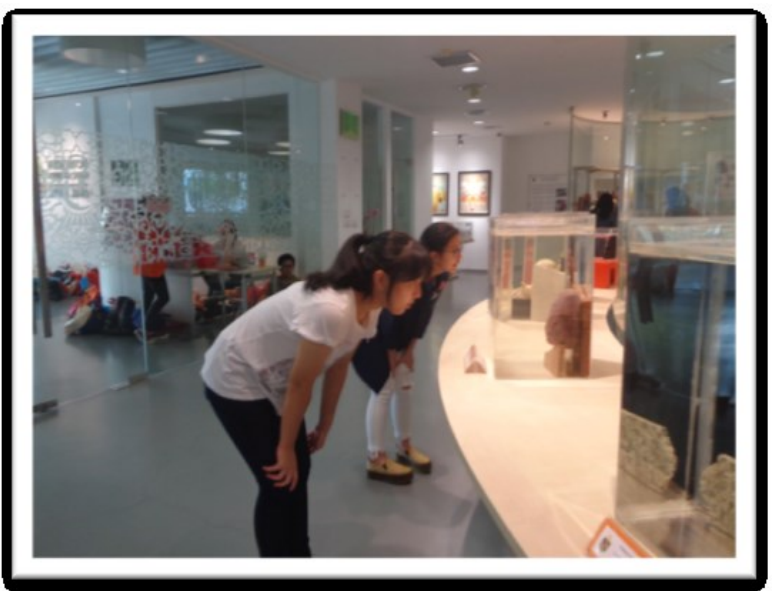

Fig. 2. Visitor at the Anatomy Museum, Faculty of Medicine Unika Atma Jaya. Documentation: Ciwuk Musiana Yudhawasthi, 2017.

In museum communication system, the messenger is not a person living today, but also someone who might probably not be able to be present because he/she has passed away or is far away from the location. In the context of ethics and cultural heritage, the museum cannot relativize the presence of the original creators; hence the museum serves to connect the knowledge between generations and even between nations. The recipients of the message have the opportunity to build the connection between the previously known concepts and objects so they obtain meaningful experience and even create meanings. The presence of museum curator reinforces the function and the condition creates unique museum's communication system. Robert Lumley in Cox concluded that in the new paradigm of museum, the role of museum is now more than merely one way communication [21]. In museum's communication system dynamic and interactive process occurs where messenger can also be the recipient of the message; likewise the recipient of the message can also be the messenger. There is an emphasis on the interpretation and relationship, information delivery and centering on meaning in the process. Both sides can provide feedback and effect of the message is intended more to the message's recipient.

University museum's communication system is illustrated in Diagram I by considering the basic variables of communication, namely messenger, message, message's recipient, feedback and effects occurring. The diagram is the model of museum's communication system which generally occurs in university museum throughout Indonesia. Components or elements of a museum are: exhibition, program, value (experience), facilities, service publications and web based activities. These are the basic components or elements which currently expected to be possessed in university museum management. Variations occur on the recency of media and variety of contents possessed by the museum. For instance, several university museums have virtual collection in the internet with various content and different displays and technology recency.

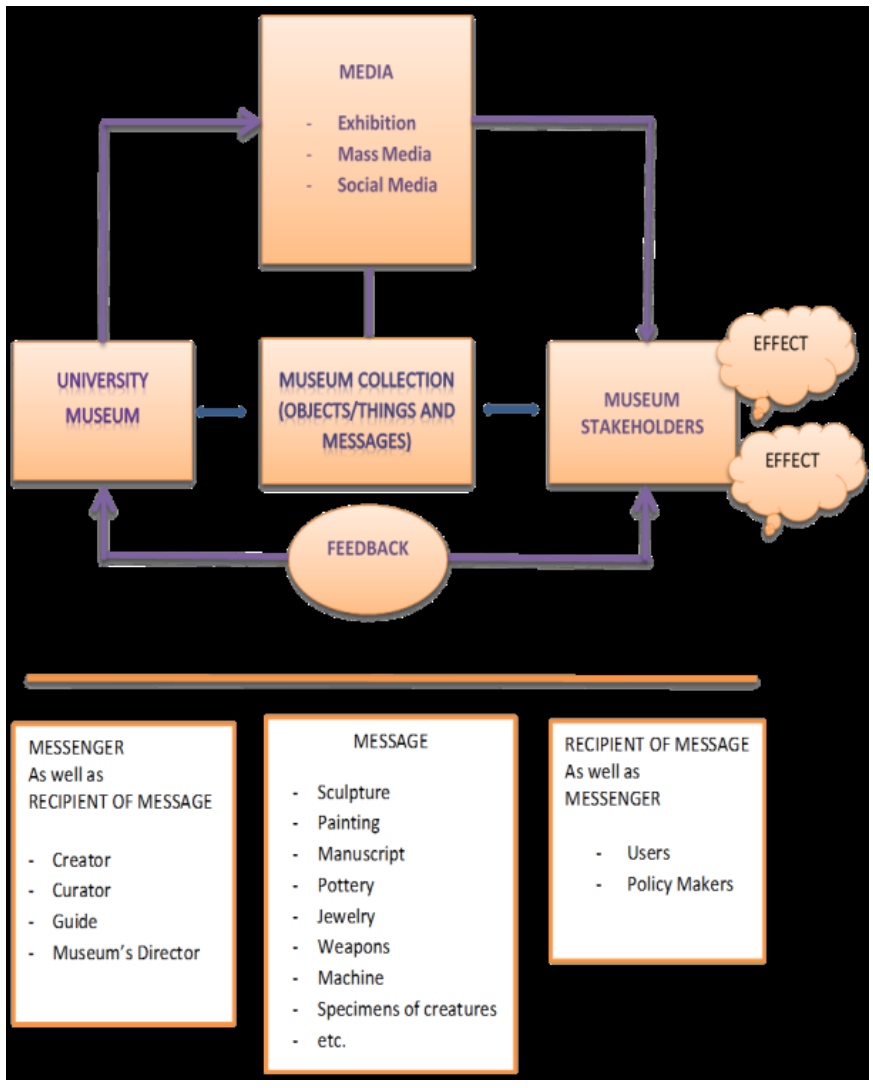

Fig. 3. Museum's Communication System

Modern university museum is a museum concept that defines itself as the center for education, research and modern recreation, as intended in the general objectives of the museum as formulated by the International Council of Museums (ICOM). In order to run the functions of university museum that are complex, outreaching and motivating the stakeholders, the role of communication becomes crucial in the development of university museum as the museum conveys information through the objects or things. According to Cameron, it is the presentation of the objects or things that distinguishes the museum as a communication system to other communication systems [22].

In achieving educational, study and pleasure objectives, a university museum is required to understand the ways of conveying information for education, research and recreation to the stakeholders effectively. According to Strong, a good exhibition should be combined with good learning and communication capability. University museum also communicates through media, alternative use of the museum building (for instance for concerts, parties, drama performances), as well as through souvenir shop and gallery [23]. University museum communicates using various methods, but according to Strong in Calderon, museum can communicate if the museum knows what communication is and museum has to have clear vision and mission [24]. 


\section{CONCLUSION}

University museum has a set of integrated variables interaction which together they create bigger pattern, therefore university museum is a communication system which consists of objects, attributes, internal relation, and non-vacuum environment. University museum is a museum that becomes a learning basis by directly involving the users to the objects. In museum's new paradigm, university museum and also other kinds of museums need to be aware of the importance of communication science use in museology to reinforce communication practice in museum.

\section{REFERENCES}

[1] ICOM, Running a Museum : a Practical Handbook. Paris: ICOM, pp. 1, 2004

[2] M. C. Laurenco, "Are University Collections and Museum Stil meaningful? Outline of a Research Project". Museologica 2, pp. 54, 2002.

[3] M. C. Laurenco, "Are University Collections and Museum Still meaningful? Outline of a Research Project". Museologica 2, 2002, pp. 58; R. Duhn, Learning from University Museum and Collection in Higher Education. London: University College London, pp. 3, 2009.

[4] M. Green, Functions of the University Museum, Symposium of the North Central Section NAGT, pp. 161, May 1969.

[5] S. Rowe, "The Role Object in Active, Distributed Meaning Making" in Perspective on Object-Centered Learning in Museums, S.G. Paris, Eds, NJ: Lawrence Erlbaum Associates, pp. 21, 2002. ; D. Romanek and B. Lynch, "Touch and Value of Object Handling: Final Conclusion for a New Sensory Museology: Policy and Practice" in Object Handling, H.J. Chaterjee, Eds, Oxford: Berg, pp. 279, 2008.

[6] D. F. Cameron, "A View Point: the Museum as a Communication System and Implication for Museum Educations". Curator, vol. 11 no. 1, pp. 33, 1968

[7] M. J. Calderon, "Museum and Communication". Philiphine Quarterly of Culture and Society, vol. 18, no. 2, pp. 137, Juni 1990.

[8] Komunitas Jelajah, Laporan Internal Survei Indonesia Museum Awards 2017, tidak diterbitkan.

[9] C. Whittel, The Museum as a Communication System : A Review and Synthesis. Eric, report research, 1997, pp. 4

[10] T. Ambrose and C. Paine, Museum Basics, London: Routledge, pp. 8 $11,2012$.
[11] N.G. Kotler, P. Kotler and W.I. Kotler, Museum Marketing and Strategy, 2nd ed, pp. 60, 2008.

[12] G. Hein, "The Constructivist Museum", Journal for Education Museum, vol. 16, no. 19, pp. 3, 1995

[13] O.U. Effendy, Ilmu Komunikasi: Teori dan Praktik. Bandung: Remaja Rosda Karya, pp. 11, 2015.

[14] S. Rowe, "The Role Object in Active, Distributed Meaning Making" in Perspective on Object-Centered Learning in Museums, S.G. Paris, Eds, NJ: Lawrence Erlbaum Associates, pp. 21, 2002. ; D. Romanek and B. Lynch, "Touch and Value of Object Handling: Final Conclusion for a New Sensory Museology: Policy and Practice" in Object Handling, H.J. Chaterjee, Eds, Oxford: Berg, pp. 279-280, 2008.

[15] E. Hooper-Greenhill, The Educational Role of Museum, London: Routledge, pp. 50, 1994

[16] S. Littlejohn and K.A. Foss, Encyclopedia of Communication Theory, pp. 950, LA: Sage, pp. 950, 2009.

[17] R. Rentscheler and A.M. Hede, Museum Marketing: Competing in Global Marketplace, Oxford: Butterworth-Heinemann, pp. 12-13, 2007 Institute Museum and Libraries Services, The Future of Museum and Libraries: A Discussion Guide, Washington D.C.: IMLS, pp. 9, 2009.

[18] S. Weaver, Creating Great Visitor Experience: A Guide for Museums, Parks, Zoos, Garden \& Libraries, CA: Walnut Creek, pp. 31, 2007.

[19] G. Hein, "The Constructivist Museum", Journal for Education Museum, vol. 16, no. 19, pp. 3-4, 1995; G. Hein, The Role of Museum in Society: Education and Social Action Paper lecture in Corfu and Athens Greece, Wahington D.C: US State Departement, 2004; S. Cox, J. Radbourne and P.M. Tidwell, "Museum Marketing: Implications for Extending The Current Literature" in Asia Pasific Advances in Consumer Research, vol 3, pp. 180, 1998; Chen H.C, Ho C.K and Ho M.C, A New Coomunication Model in Natural History Museum, Intercom Conggres, pp. 4, 2008; $\mathrm{M}$ van der Muelen, Museum Communication 2.0. The Netherland: University of Maastricht, paperwork, pp. 5, 2009.

[20] R. West and L.H. Turner, Pengantar Teori Komunikasi: Analisis dan Aplikasi, terjemahan, edisi ke-3, Jakarta: Salemba Humanika, pp. 28 2008

[21] S. Cox, J. Radbourne and P.M. Tidwell, "Museum Marketing Implications for Extending The Current Literature" in Asia Pasific Advances in Consumer Research, vol 3, pp. 180-181, 1998.

[22] D. F. Cameron, "A View Point: the Museum as a Communication System and Implication for Museum Educations". Curator, vol. 11 no. 1, pp. 33-37, 1968.

[23] M. J. Calderon, "Museum and Communication". Philiphine Quarterly of Culture and Society, vol. 18, no. 2, pp. 139-140, Juni 1990

[24] M. J. Calderon, "Museum and Communication". Philiphine Quarterly of Culture and Society, vol. 18, no. 2, pp. 138, Juni 1990 